\section{MEMBANGUN KEMANDIRIAN} PANGAN DARI RUMAH

\author{
R. Dudy Heryadi, M. Benny \\ Alexandfrí2, Deasy Silvya Sariz* \\ ${ }^{1}$ Departemen Hubungan \\ Intema sional, Universitas \\ Padjadjaran \\ 2 Departemen Administrasi Bisnis, \\ Universita s Pa dja dja ran \\ ${ }^{3}$ Departemen Hubungan \\ Intema sional, Universitas \\ Padjadjaran

\section{Artic le history} \\ Received : 22 Oktober 2020 \\ Revised : 16 J anuari 2021 \\ Accepted : 18 J anuari 2021 \\ *Corresponding author \\ Email : ${ }^{3}$ deasy.silvya@unpad.ac.id
}

No. doi:

https:// doi.org/10.24198/sa wala.v2i1.29958

\begin{abstract}
ABSTRAK
Sebagai luaran kegiatan Pengabdian Pada Masyarakat terintegrasi Kuliah Kerja Nyata Mahasiswa, artikel ini bertujuan memaparkan kegiatan-kegiatan yang mampu menyediakan supply makanan dari rumah selama social distancing. Social Distancing sebagai upaya memutus pandemi Covid-19 menuntut masyarakat untuk menjaga supply bahan makanan sebagai upaya bertahan hidup. Kemandirian pangan secara sederhana dapat dimulai dari rumah dengan membudidayakan tanaman dan ikan dengan menggunakan berbagai metode dan media tanam, mulai dari media tanah dan metode non tanah, seperti: hidroponik dan a kuaponik. Metode yang dilakukan dalam kegiatan ini adalah eksperimen. Hasil eksperimen memperlihatkan bahwa pekarangan rumah dapat dimanfaatkan untuk budidaya ta naman (sayuran) dan ikan. Dengan melihat potensi daerah sendin, kemandirian pangan dapat pula dilakukan dengan memanfaatkan produk tetangga seperti susu kambing yang dapat diolah menjadi kefir dan keju.
\end{abstract}

Kata kunci: Akuaponik, Hidroponik, Kemandirian Pangan

\section{ABSTRACT}

as an output program of Pengabdian Pada Masyarakat integrated with Kuliah Kerja Nyata Mahasiswa, this article aims to describe activities that are able to provide food supply from home during social distancing. Social Distancing as an effort to break the Covid-19 pandemic requires people to maintain food supply as an effort to survive. Food self-sufficiency can simply be started from home by cultivating plants and fish using various planting methods and media, ranging from soil media and nonsoil methods such as hydroponics and aquaponics. The method used in this activity is experiment. The experimental results show that the house yard can be used for the cultivation of plants (vegetables) and fish. By looking at the potential of the region itself, food independence can also be done by utilizing neighboring products such as goat's milk which can be processed into kefir and cheese.

Key words: Aquaponics, Food Independence, Hydroponics

\section{PENDAHULAN}

Pangan merupakan kebutuhan pokok manusia yang tetap harus terjaga ketersediaannya meski dalam kondisi pandemi. Karena kondisi pandemi Covid19 yang memungkinkan terganggunya perdagangan intemasional, ketersediaan pangan dalam negeri sangat mengandalkan produksi dari dalam negeri sendiri (Ardiyanto, 2020). Pemerintah harus mengeluarkan kebijakan yang mampu menyediakan pangan untuk konsumsi nasional (Hestina, Purba, \& Dermoredjo, 2020). Ketersediaan pangan dengan harga terjangkau bagi masyarakat merupakan sebuah tantangan bagi Kementerian Pertanian Indonesia dalam menangani dampak Covid-19 (Ha diutomo, 2020).

Pandemi Covid-19 telah mengubah tatanan kehidupan manusia. Salah satunya 
adalah perilaku social distancing. Perilaku ini menjadikan kebanyakan orang melakukan kegiatan dari rumah. Social distancing perlu dilakukan untuk memutus persebaran virus Covid-19. Mona (2020) mengemukakan perlunya melakukan social distancing dan isolasi mandin sebagai upaya penyebaran virus meski seseorang yang melakukan hal ini ini akan merasa kesepian, membosankan dan efek negatif lainnya dalam interaksi jejaring. Namun, pengorbanan itu sepadan dibandingkan dengan resiko terpapar jika mengabaikannya. Herdiana (2020) juga membahas mengenai kebijakan pemerintah pusat agar masyarakat melakukan social distancing sebagai upaya terbaik mencegah penyebaran virus covid-19, meski banyak kekurangan dalam implementasi terutama terkait dengan komunikasi antara pemerintah pusat dan daerah, serta urgensi edukasi agar masyarakat kian menyadari bahaya virus covid-19 dan taat melakukan social distancing.

Salah satu kekurangan dari social distancing adalah berkurangnya mobilitas penduduk. Mobilitas penduduk berpengaruh pada ketersediaan pasokan makanan. Ketersediaan pasokan makanan harus diupayakan untuk menjaga kelangsungan hidup. Hal ini merupakan pemikiran logis karena manusia butuh makan.

Kondisi paradoks dari pandemi dibahas oleh Ali (2020) yang menyatakan bahwa, dalam kondisi normal adalah haram hukumnya bagi laki-laki untuk berada di rumah terus-menerus yang menyebabkan ia tidak bekerja dan tidak menafkahi keluarga. Namun, dalam kondisi pandemik, secara Syariah dengan tujuan mencapai kemaslahatan yang lebih luas, social distancing peru dilakukan dalam rangka berhati-hati.

Terkait dengan kebutuhan penyediaan pangan, salah satu upaya mengadakan bahan makanan adalah dengan bercocok tanam di rumah dengan memanfaatkan sarana yang ada. Surtinah (2018) membahas mengenai budidaya sayuran di pekarangan sempit yang dilakukan oleh kelompok ibu rumah tangga. Budidaya di pekarangan sempit memiliki beberapa keuntungan seperti bebas pestisida dan mampu memberikan pendapatan per hari. Diwanti (2018) membahas mengenai memanfaatkan pekarangan rumah untuk menanam sayuran secara vertikultur dalam sebuah kegiatan pengabdian pada masyarakat, mulai dari penyulusan, pelatihan dan pendampingan masyarakat. Hobi temyata menjadi salah satu unsur dalam keinginan memanfaatkan lahan pekarangan untuk membangun ketahanan pangan dan ekonomi keluarga karena hobi mampu mendorong seseorang untuk tekun menjalani berbagai kegiatan menanam, mulai dari penyiapan media tanam, bibit tanaman, pemeliharaan (pupuk/nutrisi) (Yusuf \& Thoriq, 2018). Terlebih, memanfaatkan pekarangan untuk bibdaya tanaman selama masa pandemi Covid-19 selain mampu menyediakan pangan sendiri dari rumah, mampu memberikan pendapatan jika dilakukan dalam skala massal, juga mampu meningkatkan imunitas tubuh anggota keluarga (Qomariah, 2020).

Selain untuk budidaya tanaman, pekarangan rumah juga dapat dimanfaatkan untuk budidaya ikan. Cahyani \& Musliffah (2017) melakukan kegiatan pengabdian pada masyarakat berupa budidaya ikan lele di pekarangan rumah dengan media terpal. Kegiatan ini meliputi: pelatihan pembuatan kolam ikan lele, pelatihan pembuatan pakan lele dan pakan altematif, serta pemberian pakan agar lele tumbuh cepat dan besar. Kegiatan yang sama dilakukan oleh Zdni, Andriani, Zahidah, \& Setiawan (2018) berupa penyuluhan bubidaya ikan lele kolam terpal di desa C ipacing, J atinangor, Sumedang. Selain memberikan penyuluhan, hal yang penting dari kegiatan ini adalah proses pendampingan berupa: pendampingan pemeliharan ikan, pemberian pakan dan pengelolaan kua litas a ir.

Artikel ini bertujuan untuk memaparkan kegiatan-kegiatan yang mampu menyediakan supply makanan dari rumah selama social distancing dalam skema pengabdian pada masyarakat (PPM) yang terintegrasi dengan kuliah kerja nyata mahasiswa (KKNM) Universitas Padjadjaran periode J uli-Agustus 2020. Dalam kegiatan ini, mahasiswa melakukan kegiatan menanam sayuran dan/atau budidaya ikan di rumah. 
Artikel ini diharapkan memberikan kontribusi bagi kajian mengenai kemandirian pangan berupa memanfaatkan pekarangan rumah untuk budidaya tanaman dan ikan. Secara praktis, artikel ini diharapkan memberi inspirasi bagi para pembaca yang tertarik dengan kegiatan memanfaatkan pekarangan rumah meski dengan ukuran yang sempit.

\section{KAJ IAN PUSTAKA \\ Kemandinian Pangan}

Kemandirian pangan ada la h "kema mpuan menyediakan pangan sendiri dengan ... ind ikator: (1)tidak memasukkan unsur impor dalam proses perencanaan penyediaan pangan, (2) berupaya memandaatkan potensi domestik yang tersedia, dan (3) kejadian impor hanya merupakan kasus dimana penyediaan pangan dari dalam negeri mengalami bencana yang berakibat kegagalan produksi" (Rachmat). Ciri-cin terwujudnya kemandirian pangan ada lah (Eliza beth, 2011):

\begin{abstract}
“(i) meningkatnya produksi pangan domestik berbasis sumber daya lokal untuk penyediaan energi minimal 2.200 $\mathrm{kkal} / \mathrm{kapita} / \mathrm{hari}$, dan energi protein minimal 57 g/kapita/hari; (ii) meningkatnya land-man ratio melalui penetapan lahan abadi (irigas dan kering) masing-masing minimal 15 juta ha; (iii) meningkatkan kemampuan pengelolaan cadangan pangan; (iv) meningkatkan jangkauan jaringan distribusi dan pangan bagi produsen dan konsumen; dan (v) meningkatkan kemampuan pemerintah untuk mengantisipasi, dan menangani dini serta tanggap terhadap masalah kera wanan pangan dan gizi."
\end{abstract}

\section{Hidroponik dan Akuaponik}

Hidroponik diperkenalkan pertama kali sekitar awal 1930 oleh William Frederick Gericke di Berkeley, Califomia. Terdapat beberapa metode dalam hidroponik, ya kni: Wick System, Nutrient Fim Technique (NFT), Deep Water Culture (DWC), Drip System, dan Ebb and Flow Systems (Flood and Drain System) (Swastika, Yulfida, \& Sumitro, 2017). Hidroponik dapat menjadi altematif menanam tanaman di rumah tanpa menggunakan tanah dengan memperhatikan komposisi nutrisi selama proses tanam (Perwitasari, Tripatmasari, \&
Wasonowati, 2012). Hidroponik merupakan cara bercocok tanam dengan menggunakan media tanam sela in tanah, seperti: a ir a tau bahan la innya (kerikil, pasir, arang sekam, atau pecahan genting (Subang dalam Rahmawati, 2018) atau dapat juga menggunakan busa, kerikil, rockwool, pasir, serbuk gergaji, gambut, sabut kelapa, perlit, batu apung, kulit kacang, polester atau vermikulit (Resh dalam Swastika, Yulfida, \& Sumitro, 2017). Pemeliharaan tanaman merupakan hal yang penting dalam hidroponik. Beberapa hal yang perlu diperhatikan, yakni: pengukuran $\mathrm{pH}$ dan Nutrisi, pengendalian hama dan penyakit, penyulaman, pengontrolan instalasi, waktu panen dan penanganan pasca panen (Swastika, Yulfida, \& Sumitro, 2017). Jenis tanaman yang bisa diusahakan dengan cara hidroponik dalam kegiatan ini masih terbatas. Hal ini terjadi karena keterbatasan literatur, sarana dan pelatih sehingga arahan dalam melaksanakan kegiatan bersumber dari bahan-bahan intemet. Jenis tanaman itu di antaranya: paprika, tomat, timun Jepang, Terong Jepang, selada, seledri, melon, semangka, anggur, bluebemy, strawbemy (bibitonline, t.thn.); sawi hijau, brokoli, seledri, bayam, cabai, buncis, tomat (Prabandari, 2020); selada, mentimun, sayuran berdaun hijau, buahbuahan (melon, cabe dan tomat), tanaman herbal, dan beberapa jenis bunga (Linda, 2020).

Sela in hidroponik, a kuaponik juga menjadi salah satu solusi bercocok tanam, terutama di area perkotaan, yang memiliki kelangkaan tanah. Secara sederhana, akuaponik merupakan gabungan budidaya ikan (akuakultur) dengan budidaya tanaman tanpa media tanah (hidroponik). Akua ponik memiliki beberapa keunggulan, sepertil tidak memerlukan media tanam, pupuk, penyiraman, hemat air, sehat, bebas kontaminan, memiliki nilai estetika tinggi, menyerap polusi udara, tidak memerlukan area yang luas, serta dapat meredakan stress (Sastro, 2016). Dalam akuaponik, nutrisi untuk tanaman berasal dari feses dan ammonia hasil metabolisme ikan yang sama-sama dipelihara. Model akuaponik di antaranya ada model deep water culture (DWC), 
nutrient film technique (NFT), dan media bed (Sastro, 2015).

\section{METODE}

Kegiatan ini merupakan integrasi antara kegiatan pengabdian pada masyarakat (PPM) yang dilakukan oleh beberapa dosen fisip Unpad dan kegiatan Kuliah Kerja Nyata (KKN) virtual yang diselenggarakan oleh tim mahasiswa dalam periode Juli - Agustus 2020. Metode yang dipergunakan dalam kegiatan pengabdian ini adalah eksperimen. Secara umum, mahasiswa KKN melakukan eksperimen budidaya tanaman atau hewan a tau produk olahan yang dilakukan di rumah masing-masing. Tahapan eksperimen yang dilakukan berupa:

a. Identifikasi potensi daerah masingmasing

b. Penyesuaian potensi daerah dengan tema kegiatan

c. Pemilihan jenis budidaya yang akan dilakukan

d. Pelaksanaan budidaya tanaman atau hewan, atau komoditas la innya yang pelaporannya dilakukan secara berkala

e. Penyusunan laporan akhir

f. Publikasi hasil kegiatan ke media massa

Seiring dengan merebaknya pandemi Covid 19, kegiatan PPM yang direncanakan diubah, mulai dari bentuk menjadi kegiatan virtual, tema kegiatan pun mengalami perubahan. Perubahan tema ini bukan hal yang mudah karena kegiatan harus pula yang bisa dilakukan oleh mahasiswa di rumah masing-masing. Setelah melakukan studi literatur dan mempertimbangkan beberapa hal, terutama aspek social distancing selama pandemi, maka tim PPM mengubah tema menjadi kemandirian pangan dengan bentuk kegiatan eksperimen dimana mahasiswa peserta KKN dapat melakukan program mandiri dari rumah mereka masing-masing.

Kegiatan dimulai dari persiapan, benupa sharing tema, tujuan, pertimbangan praktis dan bentuk kegiatan. Sebelum memulai kegiatan, mahasiswa diarahkan terlebih dahulu untuk melihat potensi yang ada di sekitar tempat tinggal masing-masing. Setelah itu, baru menentukan jenis tanaman atau kegiatan apa yang hendak dilakukan.

Dalam tahap pelaksanaan, kebanyakan mahasiswa memilih tanaman yang dapat dibudidayakan secara hidroponik di rumah. J enis tanaman ini, di antaranya: sawi hijau, kangkung, bayam merah, dan selada. Ada juga yang betemak lele dengan aquaponik dan membuat produk turunan susu, seperti: kefir dan yogurt. Seluruh kegiatan selama pelaksanaan dicatat kemajuannya dalam logbook (catatan harian) yang dilaporkan secara berkala.

\section{HASLLDAN PEMBAHASAN}

Kegiatan eksperimen yang dilakukan para mahasiswa KKN di rumah masing-masing memperlihatkan adanya keberagaman budidaya tumbuhan, hewan atau komoditas la innya yang dilakukan. Setiap daerah memiliki ka rakteristik sendin, baik itu kondisi tanah, suhu, kelembapan udara, dan sebagainya yang tentu mempengaruhi jenis tanaman yang dapat dibudidayakan. Oleh karena itu, jenis tanaman yang dibudidayakan dalam kegiatan PPM-KKNM disesuaikan dengan kondisi tempat dimana mahasiswa berada dan sesuai dengan kemampuan finansial. Jenis budidaya yang dilakukan disajikan pada Tabel 1.

Tabel 1.

Jenis Budidaya yang Dilakukan

\begin{tabular}{|c|c|c|c|}
\hline $\begin{array}{l}\text { Maha } \\
\text {-siswa }\end{array}$ & Lokus & $\begin{array}{c}\text { Jenis } \\
\text { budidaya } \\
\text { yang } \\
\text { dilakukan }\end{array}$ & Metode \\
\hline 1 & $\begin{array}{l}\text { Kelurahan } \\
\text { Mangun Jaya, } \\
\text { Tambun, Bekasi }\end{array}$ & $\begin{array}{l}\text { lkan lele, } \\
\text { kangkung }\end{array}$ & Akuaponik \\
\hline 2 & $\begin{array}{l}\text { Kelurahan J ati } \\
\text { Melati, Bekasi }\end{array}$ & Kangkung & Hidroponik \\
\hline 3 & $\begin{array}{l}\text { Desa } \\
\text { Bojongsari, } \\
\text { Padaherang, } \\
\text { Pangandaran }\end{array}$ & $\begin{array}{l}\text { Kangkung, } \\
\text { Bayam, } \\
\text { Sawi, } \\
\text { Bayam } \\
\text { brazil }\end{array}$ & $\begin{array}{l}\text { Media: } \\
\text { sekam padi } \\
\text { dan limbah } \\
\text { dari } \\
\text { kandang } \\
\text { temak } \\
\text { kambing }\end{array}$ \\
\hline 4 & $\begin{array}{l}\text { Desa Cicadas, } \\
\text { Ciampea, } \\
\text { Bogor }\end{array}$ & $\begin{array}{l}\text { Bawang } \\
\text { daun }\end{array}$ & $\begin{array}{l}\text { Media } \\
\text { tanah } \\
\text { dengan } \\
\text { polybag, } \\
\text { pupuk } \\
\text { kandang }\end{array}$ \\
\hline 5 & $\begin{array}{l}\text { Desa Sumur } \\
\text { Bandung, } \\
\text { Jayanti, } \\
\text { Tangerang }\end{array}$ & $\begin{array}{l}\text { Kangkung } \\
\text { dan } \\
\text { bayam }\end{array}$ & $\begin{array}{l}\text { Media: } \\
\text { tanah, } \\
\text { sekam } \\
\text { bakar, }\end{array}$ \\
\hline
\end{tabular}




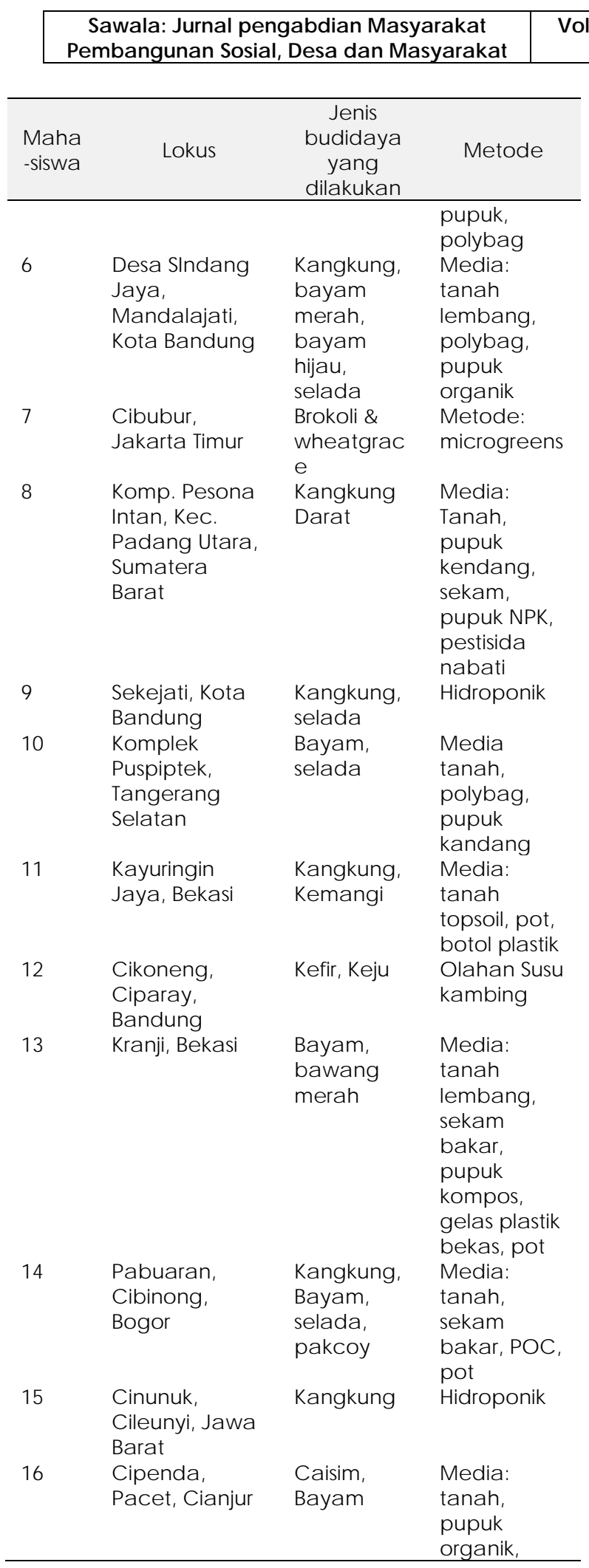

Beberapa hambatan ditemukan selama proses PPM-KKNM. Catatancatatan yang rinci dari progres keseharian menjadi pembelajaran tersendiri untuk meningkatkan pembelajaran mengenai bercocok tanam di pekarangan rumah. Beberapa kendala yang menyebabkan tanaman tidak tumbuh di antaranya: kecambah membusuk, daun menguning,

daun keriting, muncul bintik-bintik putih, layu, dan sejenisnya. Agar tanaman tumbuh baik bibitnya berasal dari biji, bibitnya baru (belum disimpan lama). Jika selama proses penyemaian bibit yang disemai tidak tumbuh menjadi kecambah, maka harus segera dibuang.

Salah satu alasan mengupayakan pangan sendiri adalah upaya mengurangi pestisida yang ada dalam sayuran yang dikonsumsi. Amilia, J oy, \& Sunardi (2016) membahas mengenai akumulasi residu pestisida pada brokoli yang berefek pada kesehatan (gejala: mual, pusing, muntah, dan gatal). Sayuran yang tadinya diharapkan memiliki kandungan vitamin dan mineral, di sisi lain dengan penggunaan pestisida berlebih benubah menjadi toksik (racun). Residu pestisida dalam sayuran tidak akan menjadi toksik jika masih berada dalam Batas Maksimal Residu (Rinawati \& Sofiatun, 2018). Kadar pestisida dalam sayuran sebenamya dapat dikurangi. Herdariani (2014) mengkaji cara mengurangi kadar pestisida dalam sayuran, khususnya kol, dengan cara pembersihan pencucian dan pemanasan. Dalam proses perendaman, misalnya, merendaman selama 5 menit, merendam menggunakan air garam, merendam menggunakan larutan jeruk, proses ini dapat mereduksi kandungan pestisida dalam kol. Keberadaan kandungan pestisida dalam sayuran tidak lepas dari perilaku petani selama proses menanam. Perila ku ini meliputi (Ameriana, 2008):

(1) persepsi petani terhadap risiko, semakin tinggi persepsi petani terhadap risiko maka semakin tinggi kuantitas pestisida kimia yang digunakan,

(2) persepsi petani tentang ketahanan kultivar tomat terhadap OPT, semakin rendah ketahanan suatu kultivar semakin tinggi kuantitas pestisida kimia yang digunakan, serta

(3) pengetahuan petani tentang bahaya pestisida, semakin rendah pengetahuan petani semakin tinggi kuantitas pestisida yang digunakan

Salah satu upaya untuk mengurangi penggunaan pestisida sintetis dalam kegiatan PPM-KKNM, nutrisi untuk tanaman diberikan dari pupuk kendang dan kompos. Bahkan, ada salah seorang mahasiswa yang membuat pupuk cair organic (POC) sendiri. POC didapatkan 
dari hasil mengompos sampah organik di rumah dan cangkang telur didapat dari sisa memasak telur. sebelum digunakan, cangkang telur dibersihkan, dikeringkan, dan dihancurkan menjadi pecahan kecil terlebih dahulu. Air yang digunakan berasal dari air PDAM (Larastiti, 2020). Cangkang telur dipergunakan karena dapat dijadikan pengganti kapur dan mampu menaikkan $\mathrm{pH}$ tanah aluvial (Mashfufah, 2014).

Pembuatan pestisida alami juga dilakukan oleh (Adila, 2020). Cara pembuatannya cukup sederhana, yakni: (1) Blender halus 500 gram daun sirih, lima batang serai dan tiga siung lengkuas; (2) Masukkan a ir 8 sampai 10 liter, tambahkan deterjen sekitar 50 gram, kemudian aduk rata; (3) Saring dengan kain halus, dan pestisida nabati ini siap dipakai; (4) Disemprotkan pada daun tanaman kangkung kurang lebih $2 \times$ seming gu. Hidroponik dan akuaponik menupakan budidaya tanaman dan ikan yang dipilih dalam kegiatan ini. Salah satu alasannya, untuk beberapa daerah yang berada di perkotaan, tanah menjadi barang yang langka. Sehingga, bercocok tanam dengan media selain tanah menjadi pilihan.

Metode hidroponik sederhana yang dilakukan dalam kegiatan PPM-KKNM adalah menanam kangkung (Aqilah, 2020). Kangkung memiliki kandungan vitamin $\mathrm{C}$ yang tinggi sehingga mampu membantu meningkatkan imunitas tubuh. Alat dan bahan yang diperlukan adalah pot plastik, baskom berlubang, botol plastik bekas 600 $\mathrm{mL}$, wadah, sendok, bibit kangkung, tisu, dan air. Proses menanam kangkung dengan metode hidroponik sederhana merupakan proses yang mudah dan tidak memakan waktu lama. Proses ini terdiri dari pembuatan la rutan nutrisi, pengisian 2 Itr air ke dalam masing-masing pot, kemudian baskom berlubang diletakkan ke dalam pot, selanjutnya letakkan tisu di atas baskom tersebut, dan terakhir letakkan bibit kangkung di atas tisu tersebut. Pembuatan nutrisi dimulai dengan mengisi wadah satu dan dua dengan $250 \mathrm{ml}$ air, kemudian tuangkan nutrisi $A$ ke dalam wadah satu dan nutrisi B ke dalam wadah dua. Selanjutnya, aduk larutan menggunakan sendok hingga nutrisi lanut sempuma. Tuangkan air ke dalam wadah satu dan dua hingga volume air masingmasing mencapai 500 ml. Kemudian, aduk kembali kedua larutan hingga tercampur rata. Setelah itu, tuangkan larutan A dan B ke dalam botol plastik bekas benukuran 600 $\mathrm{ml}$ yang telah disediakan. Terakhir, beri tanda atau label A dan B pada masingmasing botol. Setelah menanam, tahap selanjutnya adalah mengobservasi pertumbuhan bibit dan merawat tanaman tersebut dengan mengisi a ir setia $p$ hari dan la rutan nutrisi setia $p$ dua hari sekali. Setelah tiga minggu, pertumbuhan tanaman cukup baik. Namun, terdapat beberapa kendala seperti kehujanan, dan buruknya beberapa bibit kangkung sehingga pertumbuhannya tidak optimal, dan terdapat beberapa bibit yang mati.

Metode akuaponik yang dilakukan adalah budidaya lele dalam ember (Khasanna, 2020). Alat dan bahan yang diperlukan adalah: ember, gelas plastic, arang, benih lele umur 3 minggu, akar kangung, dan air. Langkah-langkah yang dilakukan adalah: (1) Siapkan air dalam ember dan diamkan selama minimal 7 hari; (2) Masukan bibit lele dalam ember yang sudah disiapkan; (3) Masukkan arang kedalam gelas aqua dan tancapkan akar kangkung ke dalamnya; (4) Pasang gelas yang sudah diisi akar kangkung, di sekeliling ember; dan (5) Tunggu selama sebulan hingga panen. Tantangan budidaya lele secara akuaponik adalah matinya lele karena pemberian pakan yang berlebih. Pakan yang tidak habis dimakan lele akan mengubah suasana air menjadi asam. Cara mengantisipasinya adalah dengan rutin mengganti air dalam ember.

Kemandirian pangan juga bisa
dilakukan dengan mengolah jenis makanan, seperti kefir dan keju sebagai bahan olahan susu. Shabira (2020) memiliki tetangga yang betemak kambing perah. la melihat susu kambing segar tetangganya berpotensi untuk dikembangkan menjadi komoditas turunan yang bemilai jual. Alat dan bahan yang diperlukan adalah 2 liter susu segar, Pla in kefir 1 liter, Wadah tupperware dan penutup, Saringan stainless, Sendok pengaduk, dan Ka in berwama gelap. Cara membuat kefir adalah sebagai berikut: (i) Susu segar dituangkan ke dalam tupperware, kemudian dituangkan juga 
plain kefir, (2) Diaduk dengan sendok pengaduk sampai plain kefir dan susu tercampur merata; (3) Setelah itu, wadah ditutup rapat agar udara tidak masuk ke dalam wadah. Lalu, wadah ditutup menggunakan ka in berwama gelap agar proses fementasi anaerob berlangsung merata. Proses fementasi berlangsung 2436 jam; (4) Hari berikutnya, ka in dan wa dah penutup dibuka; (5) Kefir diaduk kembali, kemudian disaring menggunakan stainless dan wadah lainnya. Penyaringan ini untuk memisahkan bibit kefir dan kefir susu-nya; dan (6) Kefir dituangkan dalam gelas dan siap dikonsumsi.

Susu kambing segar dapat diolah menjadi keju (Shabira, 2020). Alat dan bahan yang diperlukan adalah susu kambing segar 2 liter, cream kefir/asam kefir 500 gram, 4 telur, garam, Ka in lap bersih, Panci, Saringan stainless, Loyang, dan Kompor. Cara membuat keju adalah sebagai berikut: (1) Susu segar dipasteurisasi pada susu $47^{\circ} \mathrm{C}-60^{\circ} \mathrm{C}$ dengan api kecil setelah itu didinginkan sampai suhu 45우 ; (2) Dic a mpurkan cream kefir dengan telur dan 2 sendok makan garam, lalu diaduk sampai merata. Cream kefir ini sebagai rennet susu; (3) Api kecil dinyalakan kembali dan dituangkan campuran cream kefir ke susu secara perlahan. Diaduk sampai merata; (4) Setelah diaduk, susu dibiarkan dengan api kecil terus menyala agar proses koagulasi berlangsung dengan baik. Lama koagulasi susu pada pembuatan ini selama 45 menit; (5) Proses koagulasi selesai dengan terlihatnya curd dan whey susu. Api dimatikan lalu disiapkan loyang, saningan stainless, dan kain lap bersih; dan (6) Penyaringan dilakukan untuk memisahkan curd dan whey. Curd diperas menggunakan kain, lalu didinginkan selama 24 jam sampai membentuk padatan keju.

Proses mendorong kemandirian pangan dalam kegiatan ini dilakukan mulai dari proses sharing pemahaman mengenai urgensi kemandirian pangan berbasis lokal kepada mahasiswa peserta KKN. Pada masa pandemi kemandirian pangan kian menjadi harapan tercukupinya konsumsi pangan sehari-hari. Tahapan selanjutnya adalah identifikasi potensi daerah yang memungkinkan budidaya tanaman dan hewan yang sesuai dengan karakteristik di rumah masing-masing. Setelah itu, baru dilakukan proses eksperimen hingga pelaporannya.

Tidak semua eksperimen yang dilakukan berhasil mulus. Tentu ada dinamikanya. Misalnya, pada awal pembenihan bagus, tapi beberapa hari kemudian kecambah membusuk. Atau, tanaman sempat tumbuh, namun mengering. Untuk budidaya ikan lele, dari benih lele yang ditebar, setengahnya mati. Hal itu terjadi karena kondisi air yang terla lu banyak pakan, sehingga sisa pakan yang tidak dimakan lele mengendap dan membusuk di bawah.

$\begin{array}{cc}\text { Secara } & \text { umum, mahasiswa } \\ \text { memahami urgensi membangun }\end{array}$ kemandiran pangan dari rumah dan merespon postif. Kegiatan eksperimen yang dilakukan di rumah semacam pelatihan awal atau prototype mengenalkan Langkah-langkah yang mungkin menyediakan pangan dari rumah, meski dari semua eksperimen tidak semua berha sil. Namun, ketidakberha silan tersebut dicatat dan dibahas sehingga menjadi pembelajaran berharga untuk memperbaikinya.

\section{PENUTUP}

Kegiatan PPM-KKNM Virtual periode JuliAgustus 2020 mengambil tema membangun kemandiran pangan dari rumah. Tema ini diusung terkait dengan merebaknya pandemic Covid-19 yang mengharuskan masyakarat untuk melakukan social distancing, namun kebutuhan pangan tetap harus terjaga. Oleh karena itu, tim PPM-KKNM melakukan eksperimen budidaya tanaman dan ikan yang mungkin dilakukan di rumah dengan memanfaatkan pekarangan yang ada. Beberapa kegiatan yang dilakukan adalah menanam dengan media tanah, hidroponik dan juga akuaponik, serta mengolah produk turunan. Jenis tanaman yang dibudidayakan baik dengan media ta nah dan hidroponik a da lah sayuran yang bisa dikonsumsi sehari-hari, seperti kangkong, bayam, brokoli, bawang daun, dan sejenisnya. Budidaya ikan yang dilakukan adalah lele. Sementara produk olahan susu kambing yang dilakukan adalah kefir dan keju.

Dengan keterbatasan waktu melakukan eksperimen ini, ada beberapa 
eksperimen yang berhasil menumbuhkan tanaman dan lele serta olahan susu, ada juga yang mengalami hambatanhambatan. Bagi mahasiswa yang mengalami hambatan, mereka mencoba lagi dan mancatatkan gejalanya seperti apa sehingga dapat dievaluasi bersama.

\section{DAFTAR PUSTAKA}

Adila, L. (2020). Pemanfaatan Pekarangan Rumah melalui Teknik Budidaya Kangkung Darat dan Penggunaan Pestisida Nabati sebagai Pengandali Hama Penyakit dalam Mewujudkan Kemandinan Pangan. Sumedang: Universitas Padja dja ran.

Ali, Z Z (2020). Social Distancing Upaya Pencegahan Penyebaran Covid-19 Perspektif Maqashid al-Syariah. Nizham Joumal of Islamic Studies, 8(1), 82-94. Dipetik Oktober 20, 2020, dari

https://www.researchgate.net/public ation/342101435

Ameriana, M. (2008). Perilaku Petani Sayuran dalam menggunakan Pestisida Kimia. J. Hort, 18(1), 95-106. Dipetik Oktober 20, 2020, dari https://core.ac.uk/download/pdf/297 846009.pdf

Amilia, E., J oy, B., \& Suna rdi. (2016). Residu Pestisida pada Tanaman Hortikultura (Studi Kasus di Desa Cihanjuang Rahayu Kecamatan Parongpong Kabupaten Bandung Barat). jumal Agrikultura, 27(1), 23-29. Dipetik Oktober 22, 2020, dari http://jumal.unpad.ac.id/agrikultura/ a rtic le/viewFile/8473/3940

Aqilah. (2020). Membangun Kemandirian Pangan dari Rumah di Kelurahan Jatimelati RW 007 Kecamatan Pondok Melati Kota Bekasi Jawa Barat dengan Menanam Kangkung dengan Metode Hidroponik Sederhana di Pekarangan Rumah. Sumedang: Universitas Pa djadjaran.

bibitonline. (t.thn.). Dipetik Oktober 19, 2020, dari

https://bibitonline.com/a rtikel/11jenis-ta na ma n-hidroponik-bemila iekonomi-ting i

Cahyani, R. R., \& Musliffah, A. R. (2017). Optimalisasi Pekarangan dengan Budidaya Ikan Lele untuk Meningkatkan Pendapatan
Masyarakat. Prosiding Seminar Nasional Publikasi Hasil-hasil Penelitian dan Pengabdian Masyarakat (hal. 622-628). Semarang: Universitas Muhammadiyah Semarang. Dipetik Oktober 20, 2020, dari https://core.ac.uk/download/pdf/ 270 176458.pdf

Diwanti, S. P. (2018). Pemanfata n Pertanian Rumah Tangga (Pekarangan Rumah) dengan Teknik Budidaya Tanaman Sayuran secara Vertikultur. MARTABE: Jumal Pengabdian Masyarakat, 1(3), 101107. doi:DOI

10.31604/j.ma rtabe.v1i3.101-107

Elizabeth, R. (2011). Strategi Pencapaian Diversifikasi dan Kemandirian Pangan: Antara Harapan dan Kenyataan. Iptek Tanaman Pangan, 6(2), 230-242. Dipetik Oktober 20, 2020, dari http://pangan.litbang.pertanian.go.i d/files/08-roosganda.pdf

Herdaria ni, E. (2014, September). Identifika si residu Pestisida Kelorpirifos dalam Sayuran Kol Mentah dan Kol Siap Santap. Media Kesehatan Masya rakat Indonesia, 10(3), 154-159. doi:https://doi.org/ 10.30597/mkmi.v10 i3.489

Herdiana, D. (2020). Social Distancing: Indonesian Policy Response to the Corona Virus Disea se 2019 (Covid 19). J umal IImu Administra si, 17(1), 93-110. doi:10.31113/jia.v17i1.555

Khasanna, A. (2020). Membangun Kemandirian Pangan Keluarga di Kelurahan Mangun J aya RT 02/RW 10 Kecamatan Tambun Selatan Kabupaten Bekasi Jawa barat dengan Budidaya Ikan Lele dalam Ember. Sumedang: Universitas Padja dja ran. Dipetik Oktober 22, 2020

Kinasih, S. R. (2020). Membangun Kemandirian Pangan dari Keluarga: Studi Kasus Budidaya Bayam dan Selada di Pekarangan Rumah. Sumedang: Universitas Padjadjaran.

Larastiti, S. A. (2020). Membangun Kemandirian Pangan darii Rumah dengan Bercocok Tanam di Kelurahan Pabuaran, Kecamatan Cibinong, Kabupaten Bogor. J atina ng or: Universitas Pa dja djaran.

Linda. (2020, Mei 29). bacaterus.com. Dipetik Oktober 19, 2020, dari 
https://bacaterus.com/jenistanaman-hidroponik/

Mashfufah, N. H. (2014). Uji Potensi Pupuk Organik dari bahan Cangkang Telur untuk Pertumbuhan Tanaman Seledri (Apim graveolens L). Surakarta: Universitas Muhammadiyah Surakarta. Dipetik Oktober 22, 2020, dari

http://eprints.ums.ac.id/31650/10/nas kah_publikasi.pdf

Mona, N. (2020). Konsep Isolasi dalam Jaringan Sosial untuk Meminimalisasi Efek COntagious (Kasus Penyebaran Virus Corona di Indonesia). Jumal SOsial Humaniora Terapan, 2(2), 117125. Dipetik Oktober 21, 2020

Perwtasari, B., Tripatmasari, M., \& Wasonowati, C. (2012, Maret). Pengaruh Media Tanam dan Nutrisi terhadap Pertumbuhan dan Hasil Tanaman Pakcoi (Brassica juncea L.) dengan Sistem Hidroponik. Agrivor, 5(1), 14-25. Dipetik Oktober 19, 2020

Prabandari, A. I. (2020, April 7). Dipetik Oktober 19, 2020, dari merdeka.com: https://www.merdeka.com/sumut/7jenis-ta na man-hidroponik-sayur-yangmudah-ditanaman-cocok-untukpemula-kln.html? page $=1$

Qomariah, R. (2020, J uni 26). http://ka lsel.litbang.perta nian.go.id/.

(Badan Litbang Pertanian, Kementerian Pertanian Republik Indonesia) Dipetik Oktober 20, 2020, dari BPTP Kalimantan Selatan: http:// ka Isel.litbang.perta nia n.go.id/i $\mathrm{nd} /$ index.php? option=com_content\& view $=$ a ric le\&id =898:a d ministra to $\& \&$ a tid $=14$ : a lsin\&ltemid $=43$

Rachmat, M. (t.thn.). Kebijakan Lahan dalam Membangun Kemandirian Pangan. Dipetik Oktober 19, 2020, dari

http://www.litbang.pertanian.go.id/b uku/konversi-fra gmenta si-lahan/BABV-1.pdf

Rahmawati, E. (2018). Pengaruh berbagai Jenis Media Tanam dan Konsentrasi Nutrisi Larutan Hidroponik terhadap Pertumbuhan Tanaman Mentimun Jepang (Cucumis Sativus L). Maka sar: Fa kultas Sa ins dan Teknologi UIN Alaudin Makassar. Dipetik Oktober 19, 2020
Rinawati, D., \& Sofiatun. (2018). Kandungan Logam Berat dan Pestisida pada Sayuran segar di Kota Tangerang. Higiene: Jumal Kesehatan Lingkungan, 4(3), 169-176. Dipetik Oktober 20, 2020, dari http://joumal.uina lauddin.ac.id/index.php/higiene/arti cle/view/6254

Sastro, Y. (2015). Akuaponik: Budidaya Tanaman Terintegrasi dengan lkan, Permasalahan Keharaan dan Strategi Mengatasinya. 5(1), hal. 33-42. Dipetik Oktober 20, 2020, dari http://ja karta. litbang.pertanian.go.id/ ind/artikel\%20b ptp/buletin $\% 20$ a qua p onik\%20volume $\% 205 \% 20$ no $\% 20 \% 201 \%$ 202015

Sastro, Y. (2016). Teknologi Akuaponik mendukung Pengembangan Urban Farming. Jakarta: Balai Pengkajian Teknologi Pertanian Jakarta. Dipetik Oktober 20, 2020

Shabira, Z (2020). Membangun Kemandirian Pangan Keluarga di Desa Cikoneng, Kecamatan Ciparay, Kabupaten Bandung Jawa Barat dengan Mengolah Susu Kambing menjadi Kefir dan Keju. Sumedang: Universitas Padja dja ran.

Surtinah, N. N. (2018). Optimalisasi Pekarangan Sempit dengan Tanaman Sayuran pada Kelompok Ibu Rumah Tangga. Jumal Pengabdian dan Pemberdayaan Masyarakat, 2(2), 193-199. doi:10.30595/.jppm.v2i2.1882

Swastika, S., Yulfida, A., \& Sumitro, Y. (2017). Buku Petunjuk Teknis Budidaya Sayuruan Hidroponik (Bertanam Tanpa Media Tanah). Riau: Balai Pengkajian Teknologi Pertanian, Balitbangtan Riau. Dipetik Oktober 19, 2020

Yusuf, A., \& Thoriq, A. Z (2018). Optimalisasi Pekarangan untuk Mendukung Ketahanan Pangan dan Ekonomi Keluarga. J umal Pengabdian Kepada Masya rakat, 2(2). Dipetik Oktober 20, 2020, dari http://jumal.unpad .ac .id/pkm/article / view/16554

Zdni, I., Andriani, Y., Zahidah, \& Setiawan. (2018). Pemanfaatan Pekarangan Rumah sebagai Penyedia Protein Hewani melalui Budidaya Lele Kolam 
terpal di Desa Cipacing, Jatinangor, Sumedang, Jawa Barat. Dharmakarya: Jumal Aplikasi Ipteks untuk Masyarakat, 7(4), 248-251. doi:doi.org/10.24198/d ha maka rya.v7 i4. 20010 